\title{
Studies towards the total synthesis of halicholactone and neohalicholactone: a stereoselctive synthesis of C1-C13 fragment
}

\author{
Debendra K. Mohapatra* and Kulbhushan A. Durugkar \\ Division of Organic Chemistry: Technology, National Chemical Laboratory \\ Pune-411008, India \\ E-mail: dkm_77@yahoo.com
}

Dedicated to Professor (Mrs.) A. Chatterjee on her $85^{\text {th }}$ anniversary

(received 22 Jan 04; accepted 04 Jun 04; published on the web 10 Jun 04)

\begin{abstract}
A stereoselective synthesis of $\mathrm{C} 1-\mathrm{C} 13$ fragment of halicholactone (1a) and neohalicholactone (1b) starting from $(R)$-isopropylidene glyceraldehyde is described. Key transformations include Simmons-Smith cyclopropanation, stereoselective reduction, ring-closing metathesis (RCM).
\end{abstract}

Keywords: Oxylipins, halicholactone, cyclopropane, ring-closing metathesis, homoallyl alcohol

\section{Introduction}

Discovery in early 1960 that the marine coral Plexaura homomalla produces enormous quantities of prostaglandins ${ }^{1}$ initiated a fascinating era in the field of natural products chemistry. After this discovery, a number of secondary and non-primary metabolites produced from marine organisms have been studied extensively which often possess unusual and sometime unexpected biological activities. Interest on the part of chemists have been two fold, natural product chemists have investigated marine organisms as source of the new and unusual molecules, while synthetic organic chemists have followed by targeting these novel structures for development of new analogues and new synthetic methodologies and strategies. In 1989, secondary metabolites halicholactone (1a) and neohalicholactone (1b) showing lipoxygenase inhibitor activity were isolated from the marine sponge Halichondria okadai by the Yamada group. ${ }^{2}$ The structure of halicholactone (1a) and neohalicholactone (1b) were originally formulated on the basis of spectroscopic data and partial degradation and the relative stereochemistry by X-ray diffraction analysis of neohalicholactone (1b). ${ }^{3}$ It is likely that the halicholactone originates from transformation analogous to those represented for the constanolactones except initiated through a 15-lipoxygenase introduced hydroperoxide. 
The elegant structural and stereochemical features of halicholactone (1a) and neohalicholactone (1b) (Figure 1) decorated with dense functionalities that include an unsaturated nine-membered lactone, a trans-disubstituted cyclopropane ring and five stereocenters present a considerable challenge as synthetic targets, particularly with respect to stereochemistry and functional group sensitivity, attracted our attention to undertake its synthesis. Although, a few number of partial and total synthesis have been reported, ${ }^{4}$ the stereoselctive construction of the stereogenic centers of C-9 to C-12 is still remained to be solved.

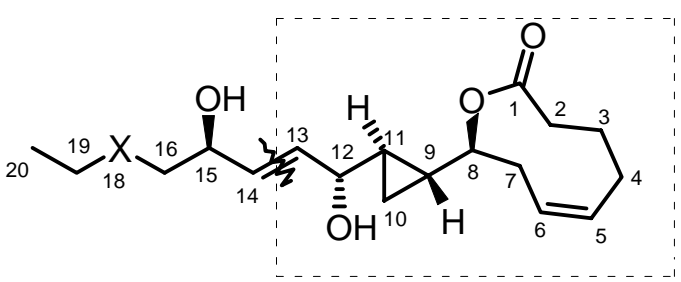

1a, $\mathrm{X}=-\mathrm{CH}_{2}-\mathrm{CH}_{2}-$ (Halicholactone) 1b, $\mathrm{X}=$ cis- $\mathrm{CH}: \mathrm{CH}$ (Neohalicholactone)

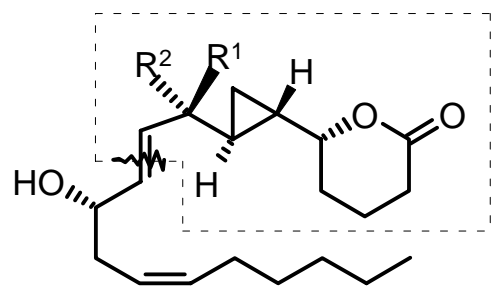

3a, $\mathrm{R}^{1}=\mathrm{H}, \mathrm{R}^{2}=\mathrm{OH}$; Constanolactone $\mathrm{A}$ 3b, $\mathrm{R}^{1}=\mathrm{OH}, \mathrm{R}^{2}=\mathrm{H}$; Constanolactone $\mathrm{B}$

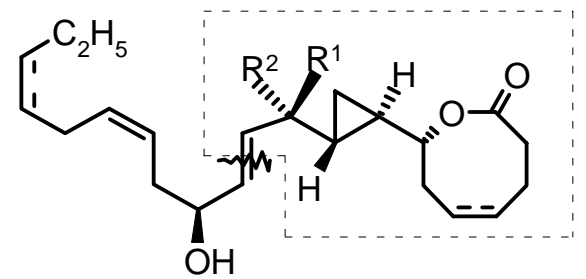

$\mathrm{R}^{1}=\mathrm{H}, \mathrm{R}^{2}=\mathrm{OH} ; \mathrm{R}^{1}=\mathrm{OH}, \mathrm{R}^{2}=\mathrm{H}$

2, Solandelactones A-H

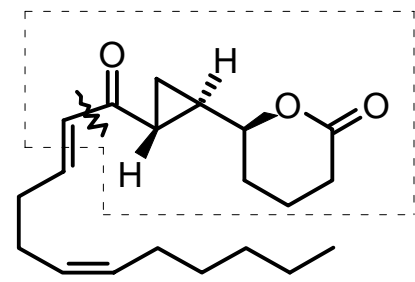

Eicosanoid 4

Figure 1. Some cyclopropyl-lactone containing oxylipins.

Our interest for the synthesis of natural products in a concise manner and to fix the stereogenic centers from C-9 to C-12 of halicholactone (1a) and neohalicholactone (1b), described herein is an efficient chiral pool approach taking (R)-2,3-O-isopropylidene glyceraldehyde (8) as the starting material as depicted in the retrosynthetic analysis (Scheme 1). 


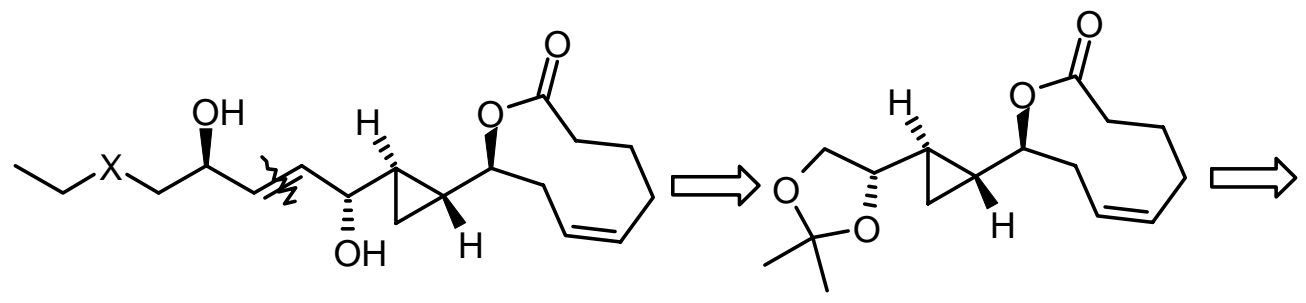

1a, $\mathrm{X}=-\mathrm{CH}_{2}-\mathrm{CH}_{2}-$ (Halicholactone)

5

1b, $\mathrm{X}=$ cis- $\mathrm{CH}: \mathrm{CH}$ (Neohalicholactone)

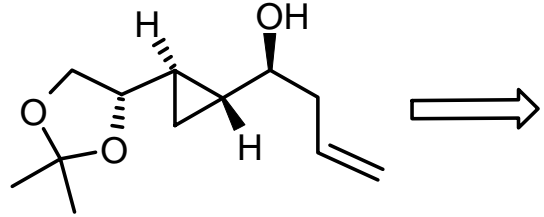

6<smiles>CC1(C)OC[C@H]([C@H]2C[C@H]2C=O)O1</smiles>

7

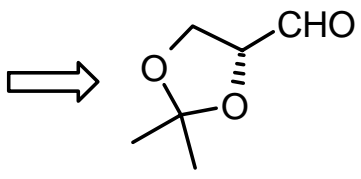

8

\section{Scheme 1}

\section{Results and Discussion}

From the retrosynthetic analysis of halicholactone (1a) and neohalicholactone (1b) (Scheme 1), the $(R)-2,3-O$-isopropylidene glyceraldehyde $(\mathbf{8})$ was chosen as suitable starting material which was converted to cyclopropyl carboxaldehyde 7 following the method reported by us. ${ }^{5}$ Subsequent addition of aldehyde 7 to allylmagnesium bromide in ether provided the homoallyl alcohol 6 and 6a as 1:1 diastereomeric mixture in 89\% yield, separable with difficulty by repeated column chromatography. This problem is however circumvented by subjecting the homoallyl alcohol mixture to oxidation under IBX $^{6}$ condition and selective reduction of the ketocompound 10 with K-selectride ${ }^{6}$ provided the diastereomers $\mathbf{6}$ and $\mathbf{6 a}$ in the ratio of 9:1.The diastereomers were separated by column chromatography (Scheme 2). The selectivity in reduction was rationalized on the basis of chelation controlled Cram's model. Interaction between cyclopropyl $\mathrm{C}-\mathrm{C}$ bonds and carbonyl $\pi$ orbitals is maximized when the cyclopropyl and carbonyl groups are oriented orthogonally. Both the bisect S-(cis) conformation and S-(trans) conformation are able to provide maximum stabilization. Mark Lautens et al. reported that treatment of tributylsilyl cyclopropyl ketone with $\mathrm{LiBH}_{4}$ resulted in a diastereomeric mixture of 2.5:1 and explained the stereoselectivity by proposing the following $S$-(cis) model. ${ }^{7}$ But S. Shuto and co-workers reported the reverse stereoselectivity with DIBAL-H (Figure 2) and it was explained by S-(trans) model. ${ }^{8}$ 

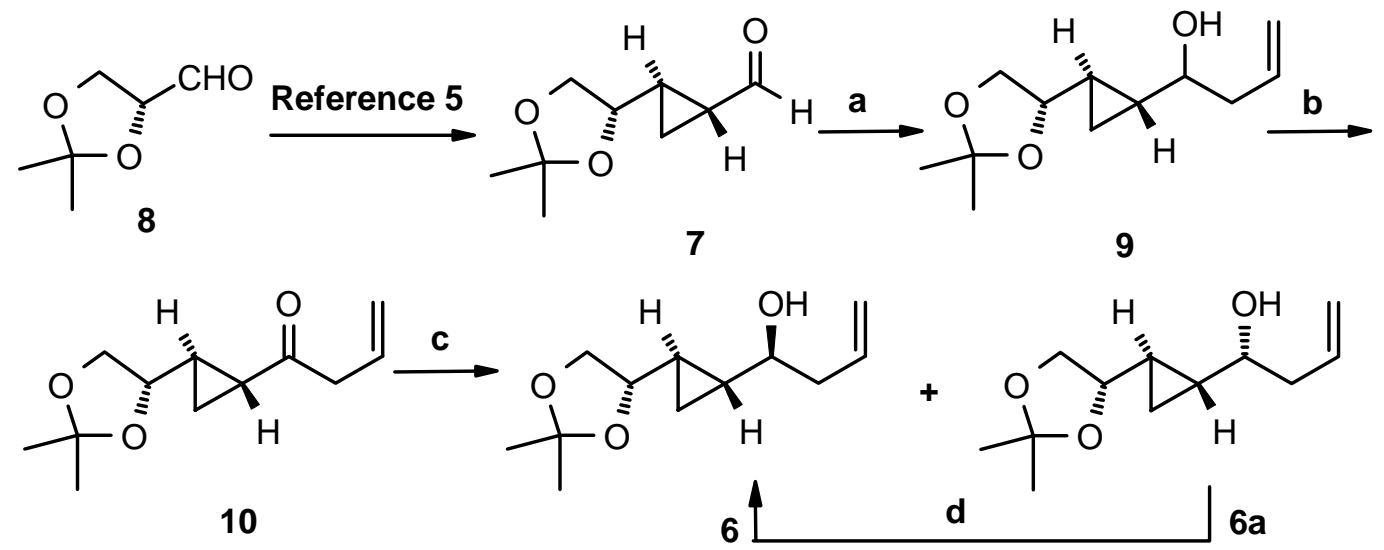

Scheme 2. Reagents and conditions: (a) $\mathrm{H}_{2} \mathrm{C}=\mathrm{CH}-\mathrm{CH}_{2} \mathrm{MgBr}, \mathrm{Et}_{2} \mathrm{O}, \mathrm{rt},(\mathbf{6} / \mathbf{6 a}=1: 1), 87 \%$; (b) IBX, DMSO, THF, 3h, 90\%; (c) K-selectride, THF, $-78^{\circ} \mathrm{C}, 4 \mathrm{~h},(6 / 6 \mathbf{a}=9: 1), 87 \%$; (d) (1) DEAD, $\mathrm{PPh}_{3}, \mathrm{AcOH}, \mathrm{THF}, 0^{\circ} \mathrm{C}$; (2) $\mathrm{K}_{2} \mathrm{CO}_{3}, \mathrm{MeOH}, \mathrm{rt}, 2 \mathrm{~h}, 76 \%$ over two steps.
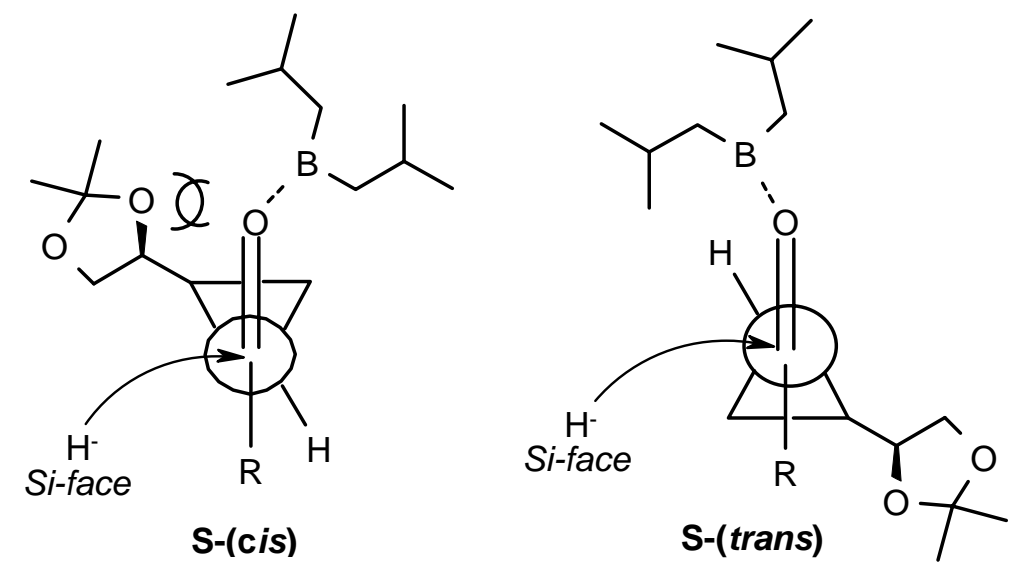

Figure 2. Conceivable transition states of the hydride reduction of cyclopropyl ketones.

When DIBAL-H is coordinated to the carbonyl group, due to steric repulsion between the two bulky isobutyl group and the substituent in the cyclopropyl group, S-(trans) conformation is preferred. The same argument holds true in the case of K-selectride, which demands a lot of steric repulsion due to its three sec-butyl groups. The newly created secondary hydroxyl group bearing center was assigned following modified Mosher's method. ${ }^{9}$ Accordingly, minor isomer 6a was converted to its $(R)$ - and (S)-(MTPA) ester with $\alpha$-methoxy- $\alpha$-(trifluoromethyl)-phenyl acetic acid which showed negative chemical shift differences $\left(\Delta \delta=\delta_{\mathrm{S}}-\delta_{\mathrm{R}}\right)$ for protons on $\mathrm{C}_{1}$ through $\mathrm{C}_{5}$ while protons on $\mathrm{C}_{7}$ through $\mathrm{C}_{9}$ showed positive differences, which is consistent with $\mathrm{C}_{6}$ bearing an $R$-configuration (Figure 3 ). The major $S$-isomer was the result of the hydride attack from the less hindered $R e$-face in the $S$-(trans) conformation. Although this manipulation gave 
the desired product $\mathbf{6}$ along with $\mathbf{6 a}$, the undesired intermediate was easily converted into $\mathbf{6}$ in $71 \%$ yield over two steps via standard Mitsunobu protocol. ${ }^{10}$

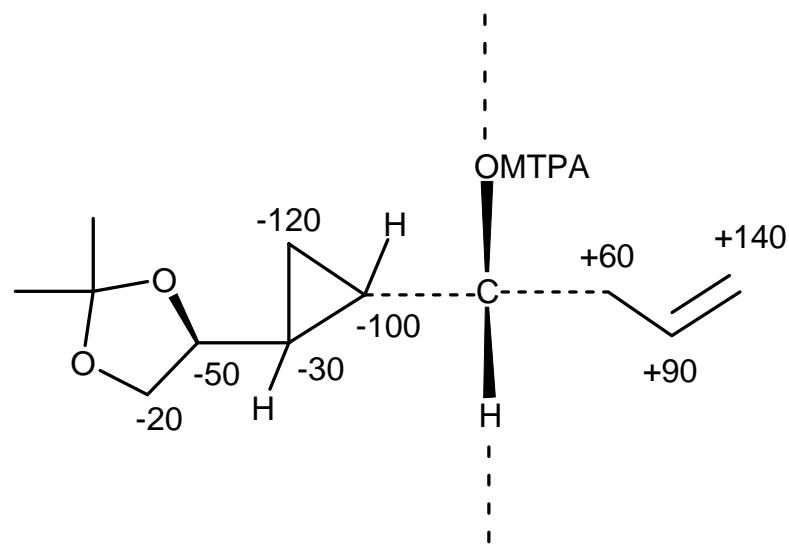

Figure 3. $\Delta \delta=\left(\delta_{\mathrm{S}}-\delta_{\mathrm{R}}\right) \times 10^{3}$ for $(R)$ - and $(S)$-MTPA esters of compound $\mathbf{6 a}$.

Having obtained the required homoallyl alcohols starting from $(R)-2$, 3-O-isopropylidene glyceraldehyde (8) in high yield and good selectivity, the next job was to construct the ninemembered lactone ring with Z-double bond. The required isomer 6 was then treated with 5hexenoic acid and EDCI in $\mathrm{CH}_{2} \mathrm{Cl}_{2}$ to afford the ester $\mathbf{1 1}$ in $92 \%$ yield. The spectral information from ${ }^{1} \mathrm{H}$ and ${ }^{13} \mathrm{C}$ NMR, IR, mass spectra and elemental analysis proved the structure $\mathbf{1 1}$ beyond doubt. In the IR spectrum, an intense peak at $1725 \mathrm{~cm}^{-1}$ indicated the presence of ester functionality. In ${ }^{1} \mathrm{H}$ NMR, two terminal olefinic protons were resonated at 5.68 and $4.98 \mathrm{ppm}$ respectively. The rest of the protons resonated at their expected chemical shift regions. The carbonyl peak of the ester functionality appeared at $172.6 \mathrm{ppm}$ and two terminal olefins at 137.7 , 133.5, 117.7 and 115.3 ppm respectively in ${ }^{13} \mathrm{C}$ NMR, confirmed the assigned structure 11.

Our final task ring-closing metathesis $(\mathrm{RCM})^{11}$ was then attempted on 11. So, treatment of 11 with Grubbs' first generation catalyst in refluxing $\mathrm{CH}_{2} \mathrm{Cl}_{2}$ provided after $24 \mathrm{~h}$ the desired ninemembered lactone 5 in 64\% yield along with the corresponding dimer 12 (10\%) (Scheme 3). In ${ }^{1} \mathrm{H} \mathrm{NMR}$, the frequencies corresponding to olefinic protons appeared at $5.46 \mathrm{ppm}$ as a multiplet, four allylic and two methylene protons adjacent to the carbonyl group resonated between 2.46 ppm to $2.07 \mathrm{ppm}$ and other protons at their respective regions. ${ }^{13} \mathrm{C}$ NMR was in consistent with the assigned structure. Cis-geometry was ascertained by comparing the ${ }^{13} \mathrm{C}$ NMR value of olefin carbons with our earlier report. ${ }^{4 a}$ IR absorption at $1739 \mathrm{~cm}^{-1}$ confirmed the lactone ring and in EIMS a signal at $\left[\mathrm{M}-\mathrm{CH}_{3}\right]^{+}$substantiated the proposed structure. It is noteworthy to mention here that the Grubbs' second generation catalyst provided the same product with high yield (76\%) and dimer $12(11 \%)$ under high dilution condition in $16 \mathrm{~h}$. The total synthesis of halicholactone (1a) and neohalicholactone (1b) can be achieved by introducing the side chains using the synthetic protocol published for the synthesis of constanolactones (3). ${ }^{12}$ 


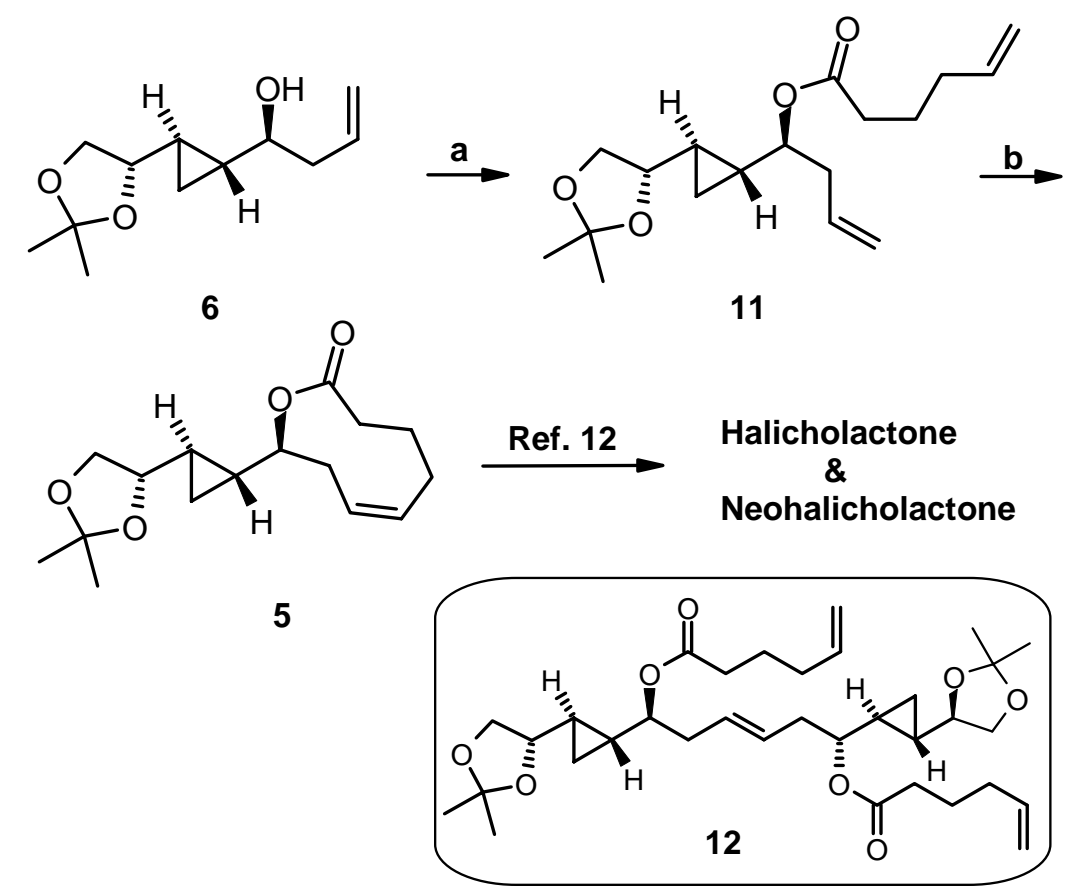

Scheme 3. Reagents and conditions: (a) 5-hexenoic acid, EDCI, $\mathrm{CH}_{2} \mathrm{Cl}_{2}, 6 \mathrm{~h}, 92 \%$; (b) $\mathrm{RuCl}_{2}=\mathrm{CHPh}\left(\mathrm{Cy}_{3} \mathrm{P}\right)(\mathrm{IEMS}), \mathrm{Ti}(\mathrm{Oi}-\mathrm{Pr})_{4}, \mathrm{CH}_{2} \mathrm{Cl}_{2}(0.1 \mathrm{mM})$, reflux, 16h, 76\%.

\section{Conclusions}

In conclusion, the present synthesis compares well with the earlier reported synthesis of the halicholactone 1a and neohalicholactone $\mathbf{1 b}$ and offers an efficient alternative route to this important class of compounds and their analogs. The strategy and the approach described is of general applicability for the formation of a library of other related compounds of structural and biological importance by simply changing the side chain as well as lactone ring size. In addition, presence of a stereodefined hydroxyl group at C-12 and a primary hydroxyl group at C-13 of compound 5 enable us to fix the stereogenic centers from C-9 to C-12 and provides the necessary functionalities required for the total synthesis of target molecules.

\section{Experimental Section}

General Procedures. Solvents were purified and dried by standard procedures before use. Column chromatography was carried out with silica gel (60-120 mesh). Infrared spectra were recorded with Shimadzu IR 470 and Perkin-Elmer 683 spectrometers. Proton NMR spectra were recorded on Bruker AC-200 machine in $\mathrm{CDCl}_{3}$ with TMS as internal standard. Mass spectra were obtained with Finningan MAT 1210 mass spectrometer. Optical rotations were measured with digital polarimeter. Elemental analysis was done on elemental analyzer model $1108 \mathrm{EA}$. All 
reactions were monitored on $0.25 \mathrm{~mm}$ E. Merck pre-coated silica gel (TLC) plates (60F-254) with UV or $\mathrm{I}_{2}$, anisaldehyde reagent in ethanol. Light petroleum refers to mixture of hexanes with bp $60-80{ }^{\circ} \mathrm{C}$.

\section{Grignard Reaction}

To an ice cooled solution of aldehyde $7(2.9 \mathrm{~g}, 17.0 \mathrm{mmol})$ in anhydrous ether $(20 \mathrm{~mL})$ was added dropwise an ether solution of allyl magnesium bromide [prepared from allyl bromide $(2.94 \mathrm{~mL}$, $34.0 \mathrm{mmol})$ and $\mathrm{Mg}(1.22 \mathrm{~g}, 51.0 \mathrm{mmol})$ in ether $(50 \mathrm{ml})]$ and stirring was continued for $3 \mathrm{~h}$ at room temperature. The reaction mixture was then quenched with $5 \% \mathrm{HCl}(20 \mathrm{ml})$ and extracted with ethyl acetate $(3 \times 50 \mathrm{ml})$. The combined organic layers were washed successively with aqueous $\mathrm{NaHCO}_{3}, \mathrm{H}_{2} \mathrm{O}$, brine and dried over $\mathrm{Na}_{2} \mathrm{SO}_{4}$ (anhydrous). The solvent was removed under reduced pressure and the crude product was purified by silica gel column chromatography using ethyl acetate/light petroleum ether (1:4) to afford $3.14 \mathrm{~g}(87 \%)$ of pure homoallyl alcohol diastereomers 9.

1-[2-[2, 2-Dimethyl-(4S)-1, 3-dioxolan-4-yl]-(1R, 2R)-cyclopropyl]-but-3-en-1-one (10). To a stirred solution of 2-iodoxybenzoic acid (IBX) $(4.95 \mathrm{~g}, 17.68 \mathrm{mmol})$ in DMSO (30 ml), was added a solution of homoallyl alcohol $9(2.50 \mathrm{~g}, 11.79 \mathrm{mmol})$ in anhydrous THF $(20 \mathrm{ml})$ at room temperature and stirring was continued for further $6 \mathrm{~h}$. After completion of the reaction (monitored by TLC), $\mathrm{H}_{2} \mathrm{O}(10 \mathrm{ml})$ was added to the reaction mixture, precipitated solid was filtered off and the filtrate was diluted with $\mathrm{H}_{2} \mathrm{O}(50 \mathrm{ml})$ and extracted with ether $(4 \times 50 \mathrm{ml})$. The combined organic layers were washed successively with aqueous $\mathrm{NaHCO}_{3}, \mathrm{H}_{2} \mathrm{O}$, brine, and dried over $\mathrm{Na}_{2} \mathrm{SO}_{4}$ (anhydrous). The solvent was removed under reduced pressure and the crude product was purified by silica gel column chromatography using ethyl acetate/light petroleum ether (1:9) to afford $2.23 \mathrm{~g}(90 \%)$ of pure cyclopropyl ketone 10. Colorless liquid; $[\alpha]_{\mathrm{D}}=-59.7$ (c 1.30, $\left.\mathrm{CHCl}_{3}\right) ;{ }^{1} \mathrm{H}$ NMR $\left(200 \mathrm{MHz}, \mathrm{CDCl}_{3}\right): \delta 1.08(\mathrm{~m}, 1 \mathrm{H}), 1.26(\mathrm{~m}, 1 \mathrm{H}), 1.34(\mathrm{~s}, 3 \mathrm{H}), 1.40(\mathrm{~s}$, $3 \mathrm{H}), 1.63(\mathrm{~m}, 1 \mathrm{H}), 1.98(\mathrm{~m}, 1 \mathrm{H}), 3.32(\mathrm{dd}, J=1.5,6.2 \mathrm{~Hz}, 1 \mathrm{H}), 3.66(\mathrm{t}, J=7.39 \mathrm{~Hz}, 1 \mathrm{H}), 3.87$ $(\mathrm{dd}, J=6.6,8.1 \mathrm{~Hz}, 1 \mathrm{H}), 5.19(\mathrm{~m}, 2 \mathrm{H}), 5.93(\mathrm{~m}, 1 \mathrm{H}) ; 13 \mathrm{C}$ NMR (50 MHz, CDCl3): 206.7, 130.5, 118.9, 109.3, 76.2, 69.1, 48.5, 26.6, 26.5, 25.6, 24.2, 14.2: Anal. Calcd for $\mathrm{C}_{12} \mathrm{H}_{18} \mathrm{O}_{3}$ (210.27): C, 68.54; H, 8.63. Found: C, 69.22; H, 8.45.

1-[2-[(2, 2)-Dimethyl-(4S)-1,3-dioxolan-4-yl]-(1R, 2R)-cyclopropyl]-(1S)-3-buten-1-ol (6 and 6a). To a stirred solution of cyclopropyl ketone $17(1.0 \mathrm{~g}, 4.76 \mathrm{mmol})$ in anhydrous THF $(30 \mathrm{ml})$, was added $\mathrm{K}$-selectride $\left(7.42 \mathrm{ml}, 7.43 \mathrm{mmol}, 1.0 \mathrm{M}\right.$ solution in THF) at $-78^{\circ} \mathrm{C}$, and stirred for $2 \mathrm{~h}$ at the same temperature. Methanol was added and the reaction mixture was brought to room temperature. After removal of the solvent at reduced pressure, the residue was treated with $2.0 \mathrm{M}$ $\mathrm{NaOH}(15 \mathrm{ml})$ solution, extracted with ethyl acetate $(2 \times 50 \mathrm{ml})$. Combined organic layers was dried over $\mathrm{Na}_{2} \mathrm{SO}_{4}$ and concentrated to afford the crude product, which on flash chromatographic separation using ethyl acetate/petroleum ether (1:4) to afford $792 \mathrm{mg}$ of major isomer 6 and $88 \mathrm{mg}$ of minor isomer $\mathbf{6 a}$.

1-[2-[(2,2)-Dimethyl-(4S)-1,3-dioxalan-4-yl]-(1R,2R)-cyclopropyl]-(1S)-3-buten-1-ol (6). Colorless liquid; ${ }^{1} \mathrm{H}$ NMR $\left(\mathrm{CDCl}_{3}\right): \delta$ 0.40-0.70 (m, 2H), 0.77-1.06 (m, 2H), $1.28(\mathrm{~s}, 3 \mathrm{H}), 1.44$ 
(s, 3H), $2.30(\mathrm{~m}, 2 \mathrm{H}), 3.05(\mathrm{~m}, 1 \mathrm{H}), 3.65(\mathrm{~m}, 3 \mathrm{H}), 4.06(\mathrm{~m}, 2 \mathrm{H}), 5.10(\mathrm{~m}, 2 \mathrm{H}), 5.84(\mathrm{~m}, 1 \mathrm{H}) ;{ }^{13} \mathrm{C}$ NMR $\left(\mathrm{CDCl}_{3}\right):$ 7.9, 18.7, 21.6, 25.6, 26.7, 69.2, 73.9, 79.1, 108.8, 118.0, 134.3; Anal. Calcd for $\mathrm{C}_{12} \mathrm{H}_{20} \mathrm{O}_{3}$ (212.29): C, 67.89; H, 9.49. Found: C, 68.24; H, 9.57.

1-[2-[(2, 2)-Dimethyl-(4S)-1,3-dioxalan-4-yl]-(1R, 2R)-cyclopropyl]-(1R)-3-buten-1-ol (6a). Colorless liquid; $\delta 0.60(\mathrm{~m}, 2 \mathrm{H}), 0.86(\mathrm{~m}, 2 \mathrm{H}), 1.28(\mathrm{~s}, 3 \mathrm{H}), 1.42(\mathrm{~s}, 3 \mathrm{H}), 1.68(\mathrm{br} \mathrm{s}, 1 \mathrm{H}), 2.30$ $(\mathrm{m}, 2 \mathrm{H}), 3.07(\mathrm{~m}, 1 \mathrm{H}), 3.60(\mathrm{~m}, 2 \mathrm{H}), 4.16(\mathrm{~m}, 1 \mathrm{H}), 5.15(\mathrm{~m}, 2 \mathrm{H}), 5.84(\mathrm{~m}, 1 \mathrm{H}) ;{ }^{13} \mathrm{C} \mathrm{NMR}$ $\left(\mathrm{CDCl}_{3}\right)$ : 7.9, 18.7, 21.6, 25.6, 26.7, 69.2, 73.9, 79.1, 108.8, 118.0, 134.3; Anal. Calcd for $\mathrm{C}_{12} \mathrm{H}_{20} \mathrm{O}_{3}$ (212.29): C, 67.89; H, 9.49. Found: C, 67.55; H, 9.26.

Mitsunobu Reaction. To a solution of $6 \mathbf{6 a}(1.2 \mathrm{~g}, 5.66 \mathrm{mmol})$ in anhydrous THF (30 ml) was added $\mathrm{PPh}_{3}(4.45 \mathrm{~g}, 16.98 \mathrm{mmol})$ and glacial acetic acid $(1 \mathrm{~mL})$ and the resultant mixture was cooled to $0^{\circ} \mathrm{C}$. To it, diethyl azodicarboxylate (DEAD) $(3.13 \mathrm{~mL}, 19.81 \mathrm{mmol})$ diluted with anhydrous THF $(5 \mathrm{ml})$ was added dropwise. The reaction mixture was then brought to room temperature and stirred overnight. After removal of the solvent, the residue was taken in $\mathrm{CH}_{2} \mathrm{Cl}_{2}$ and was washed successively with aqueous $\mathrm{NaHCO}_{3}, \mathrm{H}_{2} \mathrm{O}$, brine, and dried over $\mathrm{Na}_{2} \mathrm{SO}_{4}$ (anhydrous). The solvent was removed under reduced pressure and the crude product was dissolved in $\mathrm{MeOH}$ and treated with $\mathrm{K}_{2} \mathrm{CO}_{3}(0.3 \mathrm{~g})$. The solid was then filtered off, filtrate concentrated and the residue was purified by silica gel column chromatography using ethyl acetate/light petroleum ether (1:5) to afford $0.91 \mathrm{~g}$ (76\% after two steps) of pure homoallyl alcohol 6.

(S)-Mosher's ester. To a solution of 6a $(20 \mathrm{mg}, 0.1 \mathrm{mmol})$ in anhydrous $\mathrm{CH}_{2} \mathrm{Cl}_{2}(1 \mathrm{ml})$ was added $S$-(-)- $\alpha$-methoxy- $\alpha$-(trifluoromethyl)phenylacetic acid (S-MTPA) (35mg, $0.156 \mathrm{mmol}) \mathrm{N}$, N-dicyclohexyl carbodiimide (DCC) $(30 \mathrm{mg}, 0.17 \mathrm{mmol})$ and catalytic amount of DMAP. The reaction mixture was stirred overnight at room temperature. The solid was filtered off, filtrate concentrated and the residue was purified by silica gel column chromatography using ethyl acetate/light petroleum ether $(1: 19)$ to afford $34 \mathrm{mg}(78 \%)$ of pure $(S)$-MTPA ester. ${ }^{1} \mathrm{H}$ NMR $\left(\mathrm{CDCl}_{3}\right) \delta 0.64(\mathrm{~m}, 1 \mathrm{H}), 0.77(\mathrm{~m}, 1 \mathrm{H}), 0.94(\mathrm{~m}, 2 \mathrm{H}), 1.31(\mathrm{~s}, 3 \mathrm{H}), 1.39(\mathrm{~s}, 3 \mathrm{H}), 2.50(\mathrm{~m}, 2 \mathrm{H})$, $3.59(\mathrm{~m}, 6 \mathrm{H}), 3.98(\mathrm{~m}, 1 \mathrm{H}), 4.67(\mathrm{~m}, 1 \mathrm{H}), 5.15(\mathrm{~m}, 2 \mathrm{H}), 5.75(\mathrm{~m}, 1 \mathrm{H}), 7.40(\mathrm{~m}, 3 \mathrm{H}), 7.53(\mathrm{~m}$, $2 \mathrm{H})$.

(R)-Mosher's ester. To a solution of 6a $(20 \mathrm{mg}, 0.1 \mathrm{mmol})$ in anhydrous $\mathrm{CH}_{2} \mathrm{Cl}_{2}(1 \mathrm{ml})$ was added $R$-(-)- $\alpha$-methoxy- $\alpha$-(trifluoromethyl)phenylacetic acid (R-MTPA) (35mg, $0.156 \mathrm{mmol}$ ) $\mathrm{N}, \mathrm{N}$-dicyclohexyl carbodiimide (DCC) $(30 \mathrm{mg}, 0.17 \mathrm{mmol})$ and catalytic amount of DMAP. The reaction mixture was stirred overnight at room temperature. The solid was filtered off, filtrate concentrated and the residue was purified by silica gel column chromatography using ethyl acetate/light petroleum ether $(1: 19)$ to afford $35 \mathrm{mg}(80 \%)$ of pure $(R)$-MTPA ester. ${ }^{1} \mathrm{H}$ NMR $\left(\mathrm{CDCl}_{3}\right) \delta 0.74(\mathrm{~m}, 1 \mathrm{H}), 0.80(\mathrm{~m}, 1 \mathrm{H}), 1.06(\mathrm{~m}, 2 \mathrm{H}), 1.32(\mathrm{~s}, 3 \mathrm{H}), 1.41(\mathrm{~s}, 3 \mathrm{H}), 2.44(\mathrm{~m}, 2 \mathrm{H})$, $3.61(\mathrm{~m}, 6 \mathrm{H}), 4.03(\mathrm{~m}, 1 \mathrm{H}), 4.60(\mathrm{~m}, 1 \mathrm{H}), 5.06(\mathrm{~m}, 2 \mathrm{H}), 5.61(\mathrm{~m}, 1 \mathrm{H}), 7.40(\mathrm{~m}, 3 \mathrm{H}), 7.54(\mathrm{~m}$, $2 \mathrm{H})$.

Hex-5-enoic acid-1-[2-(2, 2-dimethyl-[1,3]dioxolan-4-yl)-(1R, 2R)-cyclopropyl]-but-3-enyl ester (11). To a solution of 5-hexenoic acid $(129 \mathrm{mg}, 1.13 \mathrm{mmol})$ in anhydrous $\mathrm{CH}_{2} \mathrm{Cl}_{2}(10 \mathrm{ml})$ was added EDCI $(269 \mathrm{mg}, 1.41 \mathrm{mmol})$ at $0^{\circ} \mathrm{C}$ and stirred for $30 \mathrm{~min}$ at the same temperature. To 
it, homoallyl alcohol $6(0.2 \mathrm{~g}, 0.94 \mathrm{mmol})$ was added. The reaction mixture was then brought to room temperature. After completion of the reaction (monitored by TLC), the reaction mixture was diluted with $\mathrm{CH}_{2} \mathrm{Cl}_{2}(15 \mathrm{ml})$ and washed with water $(2 \times 20 \mathrm{ml})$. The organic layer was dried over anhydrous $\mathrm{Na}_{2} \mathrm{SO}_{4}$, concentrated and the residue was purified by silica gel column chromatography using ethyl acetate/light petroleum ether (1:19) to afford $0.267 \mathrm{~g}(92 \%)$ of pure compound 11. Colorless viscous liquid; $[\alpha]_{\mathrm{D}}=-15.82\left(\mathrm{c}=1.19, \mathrm{CHCl}_{3}\right) ;{ }^{1} \mathrm{H} \mathrm{NMR}(200 \mathrm{MHz}$, $\left.\mathrm{CDCl}_{3}\right) \delta: 5.68$ (m, 2H, 2xCH-olefin), 4.98 (m, 4H, 2xCH -olefin), 4.30 (dd, $1 \mathrm{H}, J=6.6,14.6$ $\mathrm{Hz},-(\mathrm{C}=\mathrm{O})-\mathrm{O}-\mathrm{CH}-), 3.95$ (dd, 1H, $J=5.9,7.3 \mathrm{~Hz}, \mathrm{O}-\mathrm{CH}-), 3.52$ (m, 2H, -O-CH $\left.2^{-}\right), 2.32$ (m, 2H, $\left.-(\mathrm{C}=\mathrm{O})-\mathrm{CH}_{2^{-}}\right), 2.22\left(\mathrm{t}, 2 \mathrm{H}, J=7.7 \mathrm{~Hz},-\mathrm{CH}_{2}-\right), 2.05\left(\mathrm{dd}, 2 \mathrm{H}, J=5.8,10.2 \mathrm{~Hz},-\mathrm{CH}_{2^{-}}\right), 1.65(\mathrm{~m}$, $\left.2 \mathrm{H},-\mathrm{CH}_{2}-\right), 1.33\left(\mathrm{~s}, 3 \mathrm{H},-\mathrm{CH}_{3}\right), 1.25\left(\mathrm{~s}, 3 \mathrm{H},-\mathrm{CH}_{3}\right), 0.97$ (m, 1H, -CH-cyclopropyl), 0.84 (m, 1H, -CH-cyclopropyl), 0.65 (m, 1H, -CH-cyclopropyl), 0.51(m, 1H, -CH-cyclopropyl); IR (chloroform) $1725 \mathrm{~cm}^{-1} ;{ }^{13} \mathrm{C} \mathrm{NMR}\left(50 \mathrm{MHz}, \mathrm{CDCl}_{3}\right) \quad \delta: 172.9(\mathrm{C}=\mathrm{O}), 137.7\left(-\underline{\mathrm{CH}}=\mathrm{CH}_{2}\right), 133.5$ $\left(-\underline{\mathrm{CH}}=\mathrm{CH}_{2}\right), 117.7\left(-\mathrm{CH}=\underline{\mathrm{CH}_{2}}\right), 115.3\left(-\mathrm{CH}=\underline{\mathrm{CH}_{2}}\right), 108.9$ (-O-C-- -$), 78.5(-(\mathrm{C}=\mathrm{O})-\mathrm{O}-\underline{\mathrm{CH}}-), 75.5$ (-O-CH- $), 69.1\left(-\mathrm{O}-\underline{\mathrm{CH}}_{2}-\right), 39.0\left[-(\mathrm{C}=\mathrm{O})-\underline{\mathrm{CH}}_{2}\right], 33.8\left(-\mathrm{CH}_{2}-\right), 33.0\left(-\mathrm{CH}_{2}-\right), 26.6\left(-\mathrm{CH}_{3}\right), 25.6(-$

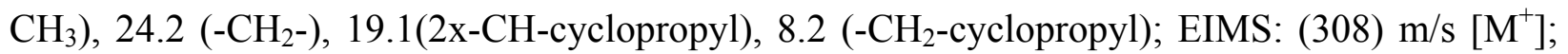
Anal. Calcd. For $\mathrm{C}_{18} \mathrm{H}_{28} \mathrm{O}_{4}$ (308.42): C, 70.10; H, 9.15. Found: C, 69.55; H,

9-[2-(2, 2-Dimethyl-[1, 3]-dioxolan-4-yl)-(1R, 2R)-cyclopropyl]-4, 5, 8, 9-tetrahydro-3Hoxonin-2-one (5). A solution of $11(0.1 \mathrm{~g}, 0.34 \mathrm{mmol})$ and freshly distilled $\mathrm{Ti}(\mathrm{Oi}-\mathrm{Pr})_{4}(0.01 \mathrm{ml}$, $0.03 \mathrm{mmol})$ in anhydrous $\mathrm{CH}_{2} \mathrm{Cl}_{2}(200 \mathrm{ml})$ was refluxed for $2 \mathrm{~h}$ under an argon atmosphere. Grubbs' "second generation" catalyst $(10 \mathrm{mg})$ in dry $\mathrm{CH}_{2} \mathrm{Cl}_{2}(5 \mathrm{ml})$ was added to it. The reaction mixture was then refluxed for $14 \mathrm{~h}$. After completion of the reaction (monitored by TLC), the reaction mixture was filtered through a pad of silica gel. The organic solvent was removed under reduced pressure and the residue was purified by silica gel column chromatography using ethyl acetate/light petroleum ether (1:9) to afford $69 \mathrm{mg}$ (76\%) of pure compound 5. Colorless liquid; $[\alpha]_{\mathrm{D}}=-56.14\left(\mathrm{c}=1.54, \mathrm{CHCl}_{3}\right) ;{ }^{1} \mathrm{H} \mathrm{NMR}\left(200 \mathrm{MHz}, \mathrm{CDCl}_{3}\right) \delta: 5.46(\mathrm{~m}, 2 \mathrm{H}, 2 \mathrm{xCH}-$ olefin $), 4.20$ $(\mathrm{m}, 1 \mathrm{H},-(\mathrm{C}=\mathrm{O})-\mathrm{O}-\mathrm{CH}-), 4.06$ (m, 1H, -O-CH-), 3.62 (m, 2H, -O-CH $\left.2_{2}\right), 2.46(\mathrm{~m}, 2 \mathrm{H},-(\mathrm{C}=\mathrm{O})-$ $\left.\mathrm{CH}_{2}-\right), 2.26\left(\mathrm{~m}, 2 \mathrm{H},-\mathrm{CH}_{2^{-}}\right), 2.07\left(\mathrm{~m}, 2 \mathrm{H},-\mathrm{CH}_{2}-\right), 1.85\left(\mathrm{~m}, 2 \mathrm{H},-\mathrm{CH}_{2-}\right), 1.41\left(\mathrm{~s}, 3 \mathrm{H},-\mathrm{CH}_{3}\right), 1.31$ $\left(\mathrm{s}, 3 \mathrm{H},-\mathrm{CH}_{3}\right), 1.00(\mathrm{~m}, 1 \mathrm{H},-\mathrm{CH}$-cyclopropyl), 0.87 (m, 1H, -CH-cyclopropyl), 0.75 (m, 1H, $\mathrm{CH}$-cyclopropyl), 0.62 (m, 1H, -CH-cyclopropyl); IR (chloroform): $1739 \mathrm{~cm}^{-1} ;{ }^{13} \mathrm{C}$ NMR (125 $\left.\mathrm{MHz}, \mathrm{CDCl}_{3}\right) \delta: 173.7(-\mathrm{C}=\mathrm{O}), 134.6$ (- $\left.\underline{\mathrm{CH}}=\mathrm{CH}-\right), 124.7$ (-CH=타- $), 109.1$ (-O-C-O-), 78.4 [$(\mathrm{C}=\mathrm{O})-\mathrm{O}-\underline{\mathrm{CH}}-\mathrm{-}, 76.2$ (-O-CH-), $69.3\left(-\mathrm{O}-\mathrm{CH}_{2}-\right), 33.9$ [-(C=O)- $\left.\underline{\mathrm{CH}}_{2}-\right], 33.6\left(-\mathrm{CH}_{2}-\right), 26.8\left(-\mathrm{CH}_{3}\right)$, 26.5 (- $\left.\mathrm{CH}_{2}-\right), 25.8\left(-\mathrm{CH}_{3}\right), 25.4\left(-\mathrm{CH}_{2}-\right), 19.6$ (-CH-cyclopropyl), 19.1 (-CH-cyclopropyl), 8.0 ($\mathrm{CH}_{2}$-cyclopropyl); EIMS: (265) m/s [M-CH$]^{+}$; Anal. Calcd. For $\mathrm{C}_{16} \mathrm{H}_{24} \mathrm{O}_{4}$ (280.37): C, 68.55; H, 8.63. Found: C, 69.12; H, 9.04. 


\section{Acknowledgements}

KAD thanks CSIR, New Delhi for award of Junior Research Fellowship. We are grateful to Dr. M. K Gurjar, Head, Organic Chemistry: Technology Division for his constant encouragement and support.

\section{References}

1. (a) Bergstrom, S.; Danielsson, H.; Samuelsson, B. Biochim. Biophys. Acta 1961, 90, 207. (b) Bergstrom, S. Science 1967, 157, 382. and references therein. (c) Corey, E. J.; Noyori, R.; Schaaf, T. K. J. Am. Chem. Soc. 1970, 92, 2586. and references therein.

2. Niwa, H.; Wakmatsu, K.; Yamada, K. Tetrahedron Lett. 1989, 30, 4543.

3. Kigoshi, H.; Niwa, H.; Yamada, K.; Stout, T. J.; Clardy, J. Tetrahedron Lett. 1991, 32, 2427.

4. (a) Mohapatra, D. K.; Datta, A. J. Org. Chem. 1998, 63, 642. (b) Baba, Y.; Saha, G.; Nakao, S.; Iwata, C.; Tanaka, T.; Ibuka, T.; Ohishi, H.; Takemoto, Y. J. Org. Chem. 2001, 66, 81. (c) Takemoto, Y.; Baba, Y.; Saha, G.; Nakao, S.; Iwata, C.; Tanaka, T.; Ibuka, T. Tetrahedron Lett. 2000, 41, 3653. (d) Critcher, D. J.; Connolly, S.; Wills, M. J. Org. Chem. 1997, 62, 6638. (e) Critcher, D. J.; Connolly, S.; Mahon, M. F.; Wills, M. J. Chem. Soc., Chem. Commun. 1995, 2, 139. (f) Critcher, D. J.; Connolly, S.; Wills, M. Tetrahedron Lett. 1995, 36, 3763.

5. (a) Morikawa, T.; Sasaki, H.; Hanai, R.; Shibuya, A.; Taguchi, T. J. Org. Chem. 1994, 59, 97.

(b) Vardarajan, S.; Mohapatra, D. K.; Datta, A. Tetrahedron Lett. 1998, 39, 1075.

6. Frigeno, M.; Santagostino, M. Tetrahedron Lett. 1994, 35, 8019.

7. Lautens, M.; Delanghe, P. H. M. J. Org. Chem. 1995, 60, 2474.

8. Kazuta, Y.; Abe, H.; Yamamoto, T.; Matsuda, A.; Shuto, S. J. Org. Chem. 2003, 68, 3511. and references therein.

9. (a) Ohtani, I.; Kusumi, J.; Kashman, Y.; Kakisawa, H. J. Am. Chem. Soc. 1991, 113, 4092.

(b) Yoshida, W. Y.; Bryan, P. J.; Baker, B. J.; McClintock, J. B. J. Org. Chem. 1995, 60, 780 .

10. Mitsunobu, O. Synthesis 1981, 1.

11. For recent reviews of olefinic metathesis, see: (a) Schuster, M.; Blechert, S. Angew Chem. Int. Ed. Engl. 1997, 36, 2037. (b) Grubbs, R. H.; Chang, S. Tetrahedron 1998, 54, 4413. (c) Armstrong, S. K. J. Chem. Soc., Perkin. Trans. 1 1998, 371. (d) Schrock, R. R. Tetrahedron 1999, 55, 8141. (e) Wright, D. L. Curr. Org. Chem. 1999, 3, 211. (f) Furstner, A. Angew Chem. Int. Ed. 2000, 39, 3012. (g) Trnka, T. M.; Grubbs, R. H. Acc. Chem. Res. 2001, 34, 18.

12. Yu. J.; Lai, J.-Y.; Ye, J.; Balu, N.; Reddy, L. M.; Duan, W.; Fogel, E. R.; Capdevila, J. H.; Falck, J. R. Tetrahedron Lett. 2002, 43, 3939. 